\title{
THE USE OF CERAMICS WITHIN THE SIGNAGE PROJECT IN HOSTILE AND ENVIRONMENTALLY PROTECTED AREAS: THE KELLER PENINSULA CASE \\ http://dx.doi.org/10.4322/apa.2014.116
}

\author{
Nicoli Santos Ferraz*, Cristina Engel de Alvarez, Mauro Pinheiro Rodrigues, Maria Regina Rodrigues
}

\begin{abstract}
Laboratório de Planejamento e Projetos, Universidade Federal do Espírito Santo - UFES, Avenue Fernando Ferrari, 514, CEMUNI I, sala 7, CEP 29075-910, Vitória, ES, Brazil
\end{abstract}

\author{
*e-mail: nicoli.ferraz@gmail.com
}

\begin{abstract}
The research goal is to measure the suitability of ceramics as a material for manufacturing sign prototypes and support components of the signage system for the Comandante Ferraz Brazilian Antarctic Station, Brazil's main base in the Antarctic region. The latter represents an environment with particular characteristics, having unique rules of occupation and material extraction and disposal, which demands a special approach when inserting any kind of foreign body to it. The methodology of tests management and suitability proofing of ceramics to the harsh Antarctic landscape conditions are split into four stages, bearing in mind that this study considers the results of the stages I and II: Stage I: identification of the ceramics properties in regard to its resistance, review of literature resources on the Antarctic environment's specificities and identification of logistic specificities concerning the Antarctic Brazilian Program (PROANTAR); Stage II: information management (feasibility, environmental impact, maintenance, and suitability of logistics); clay choice, project launching, prototype drafts, clay baking and finally manufacturing of the first prototype. According to our findings, ceramics proves to be an adequate material in the manufacturing of the component for the Keller Peninsula Signage System. The installation of a prototype in that region is scheduled for November 2012 and the test period lasts one year. After that it will be possible to draw the final conclusions and/or work on necessary adjustments.
\end{abstract}

Keywords: Signage, Ceramics, Ecodesign, Sustainability

\section{Introduction}

Since its first year of activities, in 1994, the increasing number of scientific activities conducted in Antarctica demanded consecutive expansion works of the Brazilian main base, the Comandante Ferraz Brazilian Antarctic Station (EACF). Furthermore the number of station users is also growing due to the ascension of touristic activities (PROANTAR, 2012), having direct influence on the density of traffic flow in that same region. Such scenario makes the organization of tracks and routes as well as the instruction for users becomes essential, when it comes to environmental protection, control over contingent remains production and people's safety.

The goal of this research consists in studying the performance of ceramics as an alternative material for the production of the Keller Peninsula Signage System's components.

Ceramics has been chosen as the prototype manufacturing material due to its high degree of elasticity (approx. $45.500 \mathrm{kgf} / \mathrm{mm}^{2}$ ), property which permits easy shaping, doing away with industrial production dependency. Furthermore, according to Ljungberg (2005), ceramics is adequate due to the fact that it is non-toxic, durable and resistant to corrosion. Even so, it is fragile, and its production demands high levels of electricity consumption and it has low resistance to impact.

\section{Materials and Methods}

The methodology of test management and suitability proofing of ceramics to the harsh Antarctic landscape 
conditions are split into four stages, bearing in mind that this study considers the results of the Stages I and II.

- Stage I: identification of the properties of ceramics regarding its resistance, review of literature resources on the Antarctic environment's specificities and identification of logistic specificities concerning the Brazilian Antarctic Program (PROANTAR);

- Stage II: information management (feasibility, environmental impact, maintenance, and suitability of logistics); Clay choice, project launching, prototype drafts, clay baking and finally manufacturing of the first prototype;

- Stage III: technical instructions, pieces manufacturing, assembling (tests and adjustments), disassembling, technical changes, strategy of logistics, impacts caused by the assembling of the pieces, human resources, availability of time and final results;

- Stage IV: final results evaluation.

Three distinct types of clay were used within the prototypes' manufacturing process, being two of them from a local manual production. They were extracted from the Mulembá Valley in Vitória (State of Espírito Santo-Brazil), known as Clay Z and Clay S. The third clay type is terracotta with chamote, from the Pascoal company, produced in São Paulo (State of São Paulo- Brazil).

The two native clay types are baked up to $1200^{\circ} \mathrm{C}$ and present greater flexibility, making the shaping easier. Terracota is different from types previously mentioned because its material is made up of oven baked clay, which in addition to chamote, demands less water to make it ductile, given that chamote does not absorb water (Pascoal, 2012). The dry out period is significantly shorter, as well as the baking period. Chamote increases the mechanical resistance of the baked clay piece. The terracotta-chamote mixture can be baked up to $1240^{\circ} \mathrm{C}$ and gains a particular coloration, ranging from creamy colors to red tones.

Two distinct techniques were employed during the prototypes' shaping process, i.e. 1.Shaping technique supported by a former plate, for the native clay types; 2.Production techniques with plates (Fricke, 1981), for the terracotta-chamote mixture. The techniques mentioned before were chosen because they enable, in practical ways, the development of prototypes with aerodynamic forms, according to the necessities established by the Antarctic environment.

The shaping of terracotta-chamote prototypes were made using the production techniques with plates in which two equal thick wooden boards - precisely $18 \mathrm{~mm}$ - and a rolling pin were pressed together against the clay material, giving form to the signage plates which will make up the signage structure. The water quantity consumed in this process is based on the specifications by Atterberg (Greco, 2012), i.e. the consistency limit, slightly higher than the malleability limit. Figure 1 shows each step of the process.

Due to the water loss the phenomenon of shrinkage takes place during the dry out period of solids, changing the sample's original measures. It happens simultaneously to the humidity transport, which depending upon the ongoing environmental conditions, the material's structure, and even the geometry of the plate, the dry out process can produce cracks, distortion of the shape and in the worst case breakage of the material. In order to avoid such occurrences the prototypes were covered up with newspaper, which slows down the water loss phenomenon. The prototypes made with native clay and terracotta-chamote took respectively one and two weeks to get ready.

In the course of the experiment data on the prototype's weight and dimensions were collected before and after the dry out, noticing that the weighing was made on a mechanical precision weighing balance $\pm 0,1 \mathrm{~g}$, mod. Tríplice 1610, Nwlab company. The results are displayed in Table 1.

It is essential to understand the dry out process of each clay type, given that such information is indispensable for the calculation of the final prototype size.

The baking experiments were carried out using an electric oven, from the Etil company, using $1200^{\circ} \mathrm{C}$ temperature and a duration of 20 hours.

Table 1. Prototypes weight before and after the dry up process.

\begin{tabular}{|ccccc} 
& Clay Z & Clay S & Terracota-chamote (lid) & Terracota-chamote (body) \\
\hline Weight before dry out & $480 \mathrm{~g}$ & $710 \mathrm{~g}$ & $650 \mathrm{~g}$ & $1130 \mathrm{~g}$ \\
Weight after dry out & $440 \mathrm{~g}$ & $680 \mathrm{~g}$ & $615 \mathrm{~g}$ & $1080 \mathrm{~g}$ \\
\hline
\end{tabular}

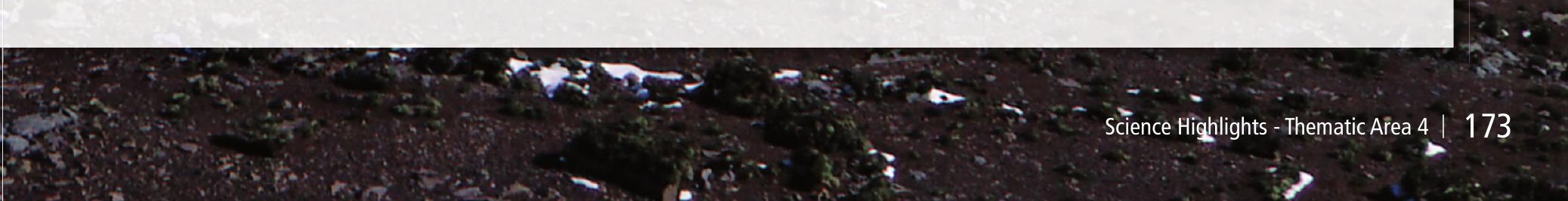


Technique supported by a former plate

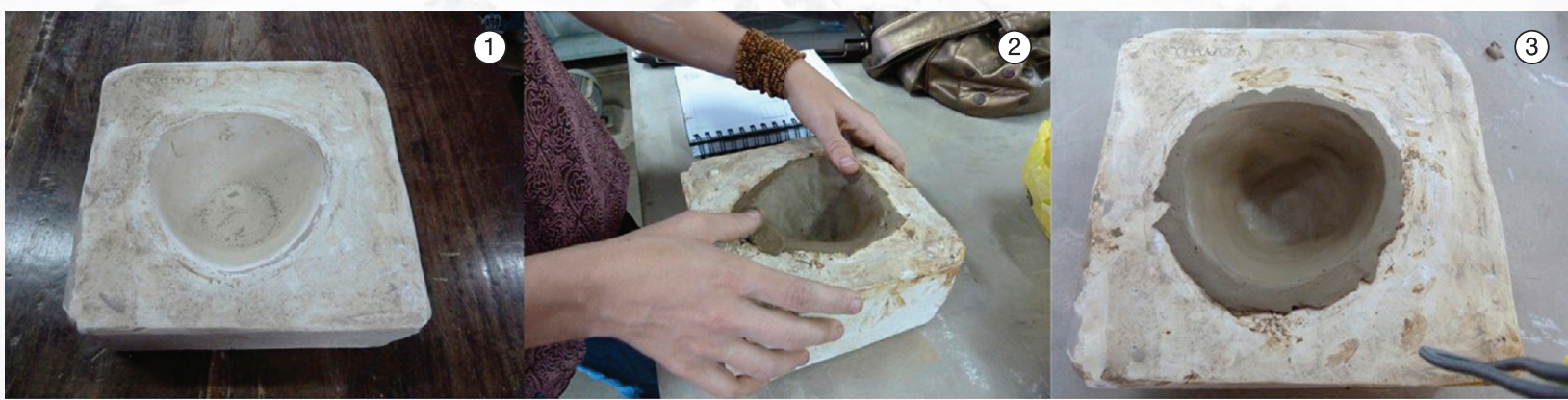

Techniques with plates
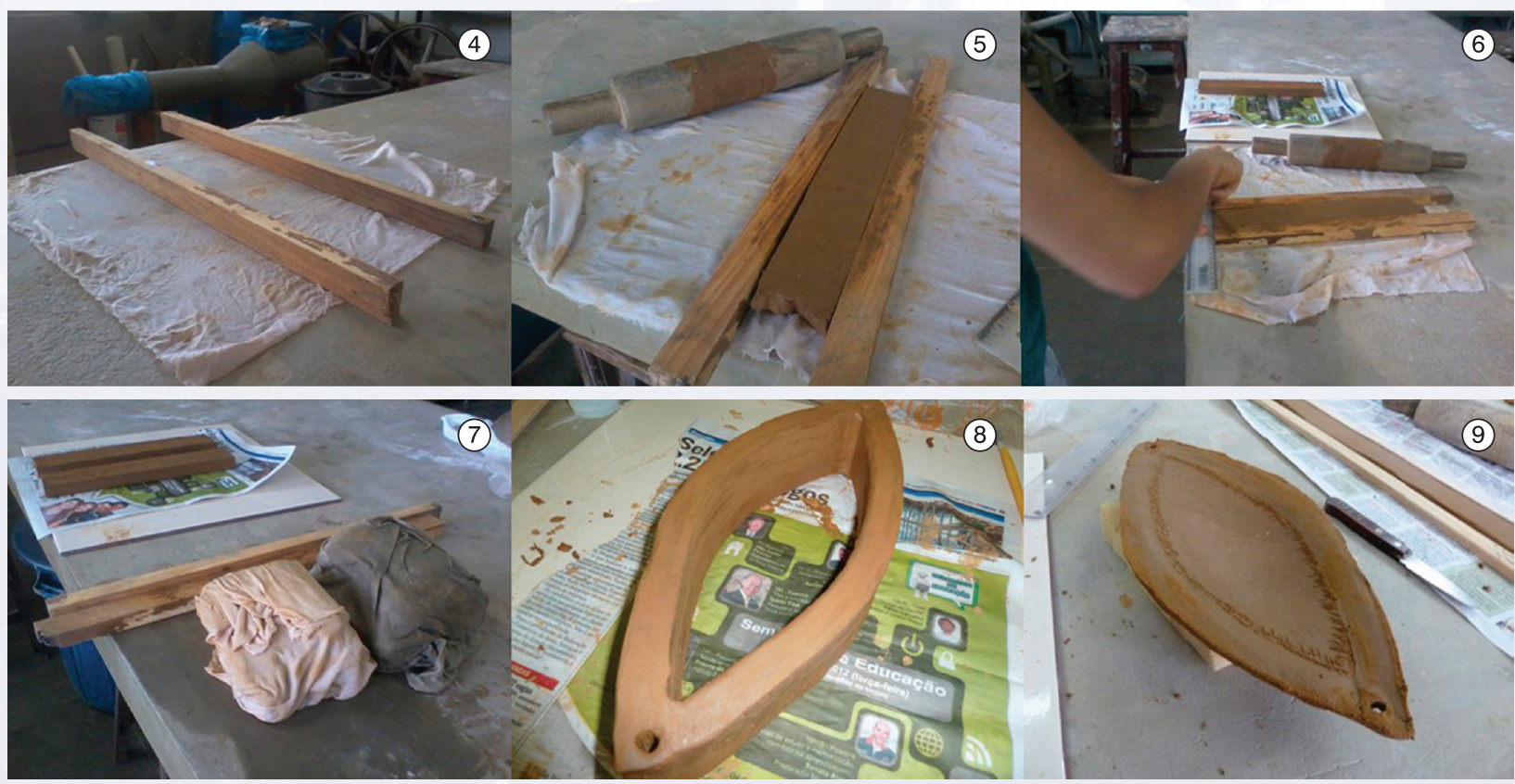

Figure 1. Detailed summary of the prototype manufacturing. Starting from the top, left to right: 1 . plaster former plate; 2 . clay material is placed into the former plate; 3 . width and surface are brushed up; 4 . Wooden boards for equal thick plate manufacturing; 5 . Plate production; 6 . width and surface brush up; 7 . ready plates and lid production; 8 . Joining the two plates resulting in an unfinished single piece; 9. Lid shaped cut plate.

\section{Discussion}

Considering that such projects are usually related to governmental programs, their implementation depends much upon human resources and materials available within the institution, or from complex public bidding processes (Alvarez, 2003). In this context, it is essential to make use of clay types which provide clear product descriptions, for instance terracotta and chamote, making the public bidding process and acquisition easier.

\section{Conclusion}

According to our findings, ceramics proves to be an adequate material in the manufacturing of the component for the Keller Peninsula Signage System.

\section{Acknowledgments}

This work integrates the National Institute of Science and Technology Antarctic Environmental Research (INCT-APA) that receives scientific and financial support 
from the National Council for Research and Development (CNPq process: $n^{\circ}$ 574018/2008-5) and Carlos Chagas Research Support Foundation of the State of Rio de Janeiro (FAPERJ n E-16/170.023/2008). The authors also acknowledge the support of the Brazilian Ministries of Science, Technology and Innovation (MCTI), of Environment (MMA) and Inter-Ministry Commission for Sea Resources (CIRM).

\section{References}

Alvarez, C.E. (2003). Metodologia para construção em áreas de difícil acesso e de interesse ambiental: aplicabilidade na Antártica e nas ilhas oceânicas brasileiras. Tese em Estruturas Ambientais Urbanas, Faculdade de Arquitetura e Urbanismo da Universidade de São Paulo. 193 p.

Fricke, J. (1981). A Cerâmica. 2. ed. Portugal: Presença. 152 p.

Greco, J.A.S. Materiais para pavimentação: Solos - Conceitos e Ensaios da Mecânica dos Solos. Available from: <http:// etg.ufmg.br/ jisela/pagina/Notas\%20de\%20aula\%20solos.pdf>. (acesso: 20 mar. 2012).

Ljungberg, L. (2005). Materials selection and design for development of sustainable products. Sweden. Materials \& Design, 28 (2): 466-479p.

Pascoal (2012). Matérias-Primas. Available from: <http://www.pascoalmassas.com.br/canais/mprimas/index.asp> . (acesso: 19 mar. 2012).

Programa Antártico Brasileiro - PROANTAR. (2010). Atividades de Turismo e outras atividades não governamentais na Antártica. Brasil. Available from: <https://www.mar.mil.br/secirm/formulario.pdf>. (acesso: 20 mar. 2012).

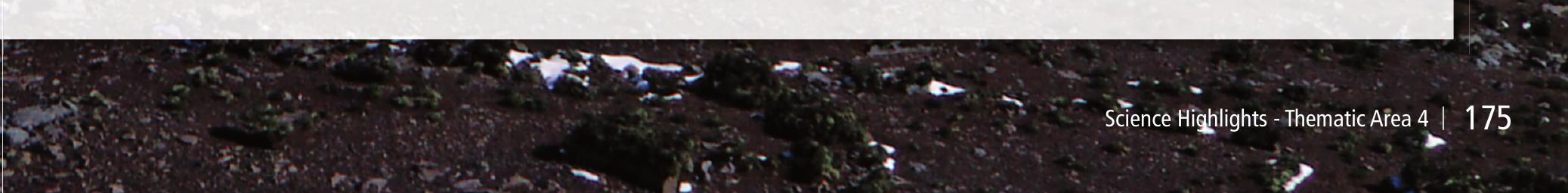

